\title{
AUTONOMIC, CARDIOVASCULAR \& PHYSIOLOGICAL RESPONSES IN STRENGTH TRAINING PROTOCOLS
}

\author{
RESPOSTAS AUTONOOMICAS, CARDIOVASCULARES E FISIOLÓGICAS EM PROTOCOLOS DE \\ TREINAMENTO DE FORÇA
}

Original Artigle

Artigo Original

Artículo Original

\section{RESPUESTAS AUTONÓMICAS, CARDIOVASCULARES Y FISIOLÓGICAS EN PROTOCOLOS DE ENTRENAMIENTO DEFUERZA}

\begin{abstract}
Andressa Formalioni' (D)
(Physical Education Professional)

Rousseau Silva da Veiga ${ }^{2}$ (ID

(Physical Education Professional)

Aline Xavier Tuchtenhagen ${ }^{2}$ (D)

(Physical Education Professional)

Léo Dutra Cabistany ${ }^{2}$ (D)

(Physical Education Professional) Fabricio Boscolo Del Vecchio² (DD

(Physical Education Professional)

1. Universidade de São Paulo (USP), School of Physical Education and Sports, São Paulo, SP, Brazil. 2. Universidade Federal de Pelotas (UFPel), Higher School of Physical Education and Sports, Pelotas, RS, Brazil.
\end{abstract}

\section{Correspondence:}

Andressa Formalioni.

Av. Corifeu de Azevedo Marques, 5680, Vila Lajeado, São Paulo, SP. Brazil, 05340-002.

andressaformalioni@usp.br

\begin{abstract}
Introduction: Strength training is a recurrent practice among several publics and the topic of several studies, yet there is a shortage of previous studies that analyzed these parameters in the same subjects in training sessions involving volume, interval and different repetitions maximum ranges. Objective: The study was aimed at measuring and comparing the acute effect of different ST (strength training) protocols on HR (heart rate), HRV (heart rate variability), [LAC] (lactate concentration), [CK] (creatine kinase) and SPE (subjective perceived exertion). Methods: Eleven individuals with previous experience were recruited and in three sessions they performed three different training models, namely: high load ( 4 sets at $90 \%$ of 1RM, 180s rest between sets), medium load (3 sets at $75 \%$ of 1 RM, 90 s rest between sets), and low load (2 sets at 50\% of 1 RM, 45 s rest between sets) in free squat, bench press, deadlift and bent-over row exercises. Results: There was no difference in CK between low load (resistance) and medium load (hypertrophy) $(p=0.60)$, between resistance and high load (strength) $(p=0.84)$, and between hypertrophy and strength $(p=0.91)$, while there was higher lactate accumulation in training with medium and low loads in comparison to training with high loads $(p<0.001)$. Conclusion: It can be noted that workouts with high loads, few repetitions and longer intervals (maximum strength) generate lower blood lactate concentrations and SPE values when compared to training with lower loads and shorter intervals (resistance training and hypertrophy). Additionally, when evaluating autonomic and cardiovascular variables, it would appear that manipulating the percentage of 1RM and the interval time does not generate significant changes in $\mathrm{HRV}$, blood pressure (BP) and $\mathrm{HR}$ when the repetitions are executed until failure. Level of evidence Il; Prospective comparative study.
\end{abstract}

Keywords: Strength training; Physiology; Heart rate control; Training programs.

\section{RESUMO}

Introdução: O treinamento de força é prática recorrente entre diversos públicos e alvo de diversos estudos, contudo há escassez de estudos prévios que analisaram esses parâmetros nos mesmos indivíduos em sessões de treino envolven do volume, intervalo e faixas distintas de repetições máximas. Objetivo: Mensurar e comparar o efeito agudo de diferentes protocolos de TF (treino de força) sobre a FC (frequência cardíaca), VFC (variabilidade da frequência cardíaca), [LAC] (concentração de lactato), [CK] (creatina quinase) e PSE (percepção subjetiva de esforço). Métodos: Foram selecionados 11 indivíduos com experiência prévia e, em três sessões, os mesmos realizaram três diferentes modelos de treino, isto é: carga alta (4 séries a 90\% de 1RM, 180s de descanso entre séries), carga média (3 séries a 75\% de 1 RM, 90s de descanso entre séries) e carga baixa (2 séries a 50\% de 1 RM, 45s de descanso entre séries) em exercícios de agachamento livre, supino reto, levantamento terra e remada curva. Resultados: Não houve diferença da CK entre a carga baixa (resistência) e a carga média (hipertrofia) $(p=0,60)$, entre resistência e carga alta (força) $(p=0,84)$ e entre hipertrofia e força $(p=0,91)$ e houve maior acúmulo de lactato nos treinos com carga média e baixa em relação ao treino com cargas altas $(p<0,001)$. Conclusão: Observa-se que os treinos com cargas altas, poucas repetições e intervalos mais longos (força máxima) geram concentrações de lactato sanguíneo e PSE menores quando comparados aos treinos que utilizam cargas mais baixas e intervalos mais curtos (treinos de resistência e hipertrofia). Adicionalmente, quando avaliadas as variáveis autonômicas e cardiovasculares, parece que manipular o percentual de IRM e o tempo de intervalo não écapaz de gerar alterações significativas na VFC, pressão arterial (PA) e FC quando as repetições são executadas até a falha. Nível de evidência ll; Estudo prospectivo comparativo.

Descritores: Treinamento de força; Fisiologia; Controle da frequência cardíaca; Programas de treinamento.

\section{RESUMEN}

Introducción: El entrenamiento de fuerza es práctica recurrente entre diversos públicos y objetivo de diversos estudios. Sin embargo, hay escasez de estudios previos que analizaron esos parámetros en los mismos individuos en sesiones de entrenamiento abarcando volumen, intervalo y franjas distintas de repeticiones máximas. Objetivo: Medir y comparar el efecto agudo de diferentes protocolos de EF (entrenamiento de fuerza) sobre la FC (frecuencia cardíaca), VFC (variabilidad de la frecuencia cardíaca), [LAC] (concentración de lactato), [CK] (creatina quinasa) y PSE (percepción 
subjetiva de esfuerzo). Métodos: Fueron seleccionados 11 individuos con experiencia previa y, en tres sesiones, los mismos realizaron tres modelos de entrenamiento, a saber: carga alta (4 series a 90\% de 1RM, 180s de descanso entre series), carga mediana (3 series a 75\% 1RM, 90s de descanso entre series), y carga baja (2 series a 50\% de 1RM, 45s de descanso entre series) en los ejercicios de agachamiento libre, supino recto, levantamiento tierra y remada curva. Resultados: No hubo diferencias de la CKentre la carga baja (resistencia) y la carga mediana (hipertrofia) $(p=0,60)$ entre resistencia y carga alta (fuerza) $(p=0,84)$ y entre hipertrofia y fuerza $(p=0,91)$ y hubo mayor acumulación de lactato en los entrenamientos con carga mediana y baja con relación al entrenamiento con cargas altas $(p<0,001)$. Conclusión: Se observa que los entrenamientos con cargas altas, pocas repeticiones e intervalos más largos (fuerza máxima) generan concentraciones de lactato sanguíneo y PSE menores cuando comparados a los entrenamientos que utilizan cargas más bajas e intervalos más cortos (entrenamientos de resistencia e hipertrofia). Además, cuando evaluadas las variables autonómicas y cardiovasculares, parece que manipular el porcentaje de 1RM y el tiempo de intervalo no es capaz de generar alteraciones significativas en la VFC, presión arterial (PA) y FC cuando las repeticiones son ejecutadas hasta la falla. Nivel de evidencia ll; Estudio prospectivo comparativo.

Descriptores: Entrenamiento de fuerza; Fisiología; Control de la frecuencia cardíaca; Programas de entrenamiento.

\section{INTRODUCTION}

Strength training has been widely employed to improve fitness levels of athletes ${ }^{1}$ and healthy people, ${ }^{2}$ and in the prevention of and recovery from different health conditions. Besides increased strength endurance, maximum strength and power, ${ }^{3}$ improvements in bone mass, ${ }^{4}$ muscle hypertrophy ${ }^{5}$ and weight loss $^{6}$ can also be identified as a result of its practice. However, ST protocols are quite diverse, ${ }^{7}$ as they involve several variables and studies of acute physiological responses in different training protocols predominantly analyze creatine kinase $[C K],{ }^{8}$ blood lactate $([\mathrm{LAC}]),{ }^{9}$ subjective perceived exertion $(\mathrm{SPE})^{10}$ and total training volume. ${ }^{11}$ In contrast, there is a shortage of previous investigations analyzing these and other physiological parameters in ST sessions with different repetitions maximum ranges.

Additionally, the use of SPE to modulate ST intensity appears feasible, and it has a good relationship with heart rate $(\mathrm{HR}) .^{12}$ From the metabolic point of view, a greater elevation of [LAC] can be observed in training with lower loads and a higher number of repetitions compared to training with higher loads and a lower number of repetitions. ${ }^{13}$ Moreover, sessions of greater intensity tend to produce greater tissue damage ${ }_{1}^{14}$ based on creatinine kinase [CK] levels.

On the other hand, recent studies have indicated that ST may impact the central nervous system, and to quantify this action, heart rate variability (HRV) has proven an effective tool for quantifying autonomic activity. ${ }^{15}$ Previous investigations analyzing the acute effect of strength training on HRV behavior have indicated a decrease in variables related to the domain of time ${ }^{16}$ and high frequency, ${ }_{1}^{17}$ while low frequency values increase. ${ }^{18}$

However, data on the impact of different ST protocols on different physiological variables are scarce and contradictory, thus highlighting the relevance of studies on the topic. Accordingly, the purpose of this particular study was to measure and compare the acute effect of different ST protocols on HR, HRV, [LAC], [CK] and SPE.

\section{MATERIALS AND METHODS}

The study is characterized as experimental. Eleven normotensive male subjects, aged 18 to 35 years and with more than six months of experience in strength training, recruited as a convenience sample, were involved. Determination of sample size considered previously published data on [CK] in ST, due to the less responsive variable among those investigated in this particular study. Considering mean of the differences of $90 \mathrm{U} \cdot \mathrm{L}^{-1}$, standard deviation of the differences of $105 \mathrm{U} \cdot \mathrm{L}^{-1},{ }^{19}$ power of $80 \%$ and significance level of $5 \%$, ten observations per group would be necessary. Thus, after adding 10\% for losses, eleven participants were recruited. Individuals with heart conditions, severe respiratory diseases or a recent history of seizures, and subjects with musculoskeletal disorders that prevented them from undertaking the training routines were excluded from the sample. Participants read and signed an Informed Consent Form and the research project was approved by the local institutional review board (68577917.0.1001.5313).

The participants made four visits to the laboratory. During the first of these, a one repetition maximum (1RM) test was performed in the free squat, bench press, deadlift and bent-over row exercises, in this respective order. In the three subsequent sessions, the participants performed three different training models, namely: high load (4 sets at $90 \%$ of $1 \mathrm{RM}, 180$ s rest between sets), medium load ( 3 sets at $75 \%$ of $1 \mathrm{RM}, 90$ s rest between sets), and low load ( 2 sets at $50 \%$ of 1 RM, 45 s rest between sets). ${ }^{20}$ Participants were asked to perform repetitions until momentary concentric failure in all sets, which was defined as the inability to complete the concentric phase of a repetition without changing the movement pattern of the prescribed exercise. All exercises were performed with a $20 \mathrm{~kg}$ Olympic dumbbell bar and rubber washers (Ziva ${ }^{\mathrm{TM}}$, Beijing, China).

To determine the training load, a prior session was held to identify the load corresponding to 1RM. ${ }^{3}$ After standardized warm-ups with submaximal loads, using between 10-15 repetitions, the subject attempted the load for 1RM. When successful, the subject was allowed to recover for 3 minutes before the load was increased. In the event of failure, the subject was allowed to recover for $3 \mathrm{~min}$ and the load was reduced by up to $5 \%$ for upper limbs and up to 10\% for lower limbs before attempting the RM once again.

Prior to the execution of the protocols employed, participants performed standardized general warm-up using complex training adaptation ${ }^{21}$ composed of squats, bench press, deadlift and bent-over row exercises, with two sets of six repetitions in each exercise, no break for rest between them and 50 jumping jacks between sets. ${ }^{22}$ The warm-up load corresponded to the Olympic bar (20kg).

To undertake the sessions (table 1), subjects needed to have spent at least $48 \mathrm{~h}$ without performing any type of exercise, and the interval between the three experimental sessions was supposed to be 5-7 days. For all sessions, which occurred in pre-defined order (low load, medium load and high load, respectively), the exercises performed were: free squat, bench press, deadlift and bent-over row, in the respective sequence.

Table 1. Description of the training sessions.

\begin{tabular}{c|c|c}
\hline Session $\mathbf{1}$ - low load & Session $\mathbf{2}$ - medium load & Session $\mathbf{3}$ - high load \\
\hline $\mathbf{2}$ sets & $\mathbf{3}$ sets & $\mathbf{4}$ sets \\
\hline $\begin{array}{c}45 \text { s interval between } \\
\text { exercises and sets }\end{array}$ & $\begin{array}{c}\text { 90s interval between } \\
\text { exercises and sets }\end{array}$ & $\begin{array}{c}180 \text { s interval between } \\
\text { exercises and sets }\end{array}$ \\
\hline $50 \%$ of the load of 1RM & $75 \%$ of the load of 1RM & $90 \%$ of the load of 1RM \\
\hline
\end{tabular}




\section{Data collection and recording procedures}

Lactate Concentration: [LAC] was measured before, immediately after, and $5 \mathrm{~min}$ after each protocol. The collection involved puncturing the earlobe to draw $15 \mu \mathrm{L}$ of blood, which was immediately analyzed using Yellow Spring Instruments electrochemical equipment, model 2300 Sport (OH, USA). Creatine Kinase Concentration: To measure [CK], 32 $\mu \mathrm{L}$ of capillary blood was drawn by puncturing the earlobe, and transferred to reagent strip (ANVISA 10287410157, Reflotron ${ }^{\circledR}$ ), which was read by portable analyzer (Reflotron Analyser ${ }^{\circledR}$, Boehringer-Mannheim, France). This procedure was performed immediately before the first session and $24 \mathrm{~h}$ after each training session. Subjective Perceived Exertion: SPE was measured using the Borg Scale ${ }^{23}$ after each training session.

Heart rate variability: A cardiac monitor (Polar RS800CX; Kempele, Finland $)^{24}$ was used to record HRV. The data were recorded at the following time points: pre-warm-up, soon afterwards and $24 \mathrm{~h}$ after each training session held. Samples were collected with the subject lying in the dorsal decubitus position and remaining immobile for $5 \mathrm{~min} .{ }^{15}$ The data were processed using version 5.0 of the Polar Pro Trainer software, and were then exported to Kubios HRV Software, v.2, where the variables of the following domains were analyzed: I) time, with the mean time between two heart beats (Mean RR), mean number of heart beats per minute (Mean HR), standard deviation of normal-to-normal RR intervals (SDNN), root mean square of successive RR-interval differences (RMSSD);II) frequency, high (HF), low (LF), very low (VLF), and LF/HF ratio; III) nonlinear with the variables standard deviation between instantaneous points (SD1) and standard deviation of long-term trend (SD2). ${ }^{15}$

Blood Pressure: BP was measured at rest (before warm-up) and at the end of the last set of each exercise in the three sessions. Measurements were taken using an aneroid sphygmomanometer and stethoscope (P.A. MED ${ }^{\circledR}$ KPA200).

\section{Statistical analysis}

Descriptive data are presented as mean and standard deviation. One-way ANOVA was used to analyze the variables that were collected at up to two time points (SPE and CK), while two-way ANOVA was used for the others, considering training and timing. The Bonferroni post hoc test was used. Data were tabulated in Excel and statistical procedures were conducted in SPSS, version 20.0.

\section{RESULTS}

Regarding the characteristics of the sample, the eleven study participants were aged $25 \pm 4$ years, with a height of $179.5 \pm 7 \mathrm{~cm}$ and weight of $78.9 \pm 6 \mathrm{~kg}$. As regards to practice time, the mean time was $54 \pm 35.7$ months (minimum $=12$ and maximum $=120$ months), with weekly frequency of $4 \pm 0.8$ sessions.

Regarding the weight used and respective range of repetitions, Table 2 shows a significant difference between the protocols adopted in terms of the number of repetitions $(F=57.81)(p<.0001)$ and total weight adopted $(F=25.91)(p<.0001)$.

The results of the mean values of [LAC] are presented in Figure 1 and indicate a difference between the workouts with high load and the others. Training $(2.30)=30.264 ; p<0.001$; timing $(2.60)=296.414$; $p<0.001$; interaction $(4.60)=15.138 ; p<0.01$. Training with high load had inferior results at the two post-training time points when compared to resistance and hypertrophy training $(p<0.001)$, yet there were no differences between resistance and hypertrophy $(p=0.15)$.

Table 2. Total weight and range of repetitions for each training protocol (mean \pm sd).

\begin{tabular}{c|c|c}
\hline Type of load & Session weight & Range of repetitions \\
\hline Low & $220.4 \pm 29.27$ & $130.3 \pm 20.24$ \\
\hline Medium & $318.0 \pm 53.98$ & $104.0 \pm 6.48$ \\
\hline High & $382.55 \pm 70.81$ & $71.82 \pm 7.78$ \\
\hline
\end{tabular}

Weight for all the exercises proposed in the session.
With regards to [CK] (Figure 2), the three training models showed no differences when the post-training time points were compared between low load (resistance) and medium load (hypertrophy) $(p=0.60)$, resistance and high load (strength) ( $p=0.84)$, and between hypertrophy and strength $(p=0.91)$.

With regards to SPE (Figure 3 ) there was significant difference $(f=10.266$ and $p<0.001)$ for maximum strength training (mean $=14)$, where lower values were found for both resistance training (mean $=17.8 ; p<0.001)$ and hypertrophy training (mean $=16.3 ; p<0.05$ ). There were no differences between resistance and hypertrophy training $(p=0.17)$.

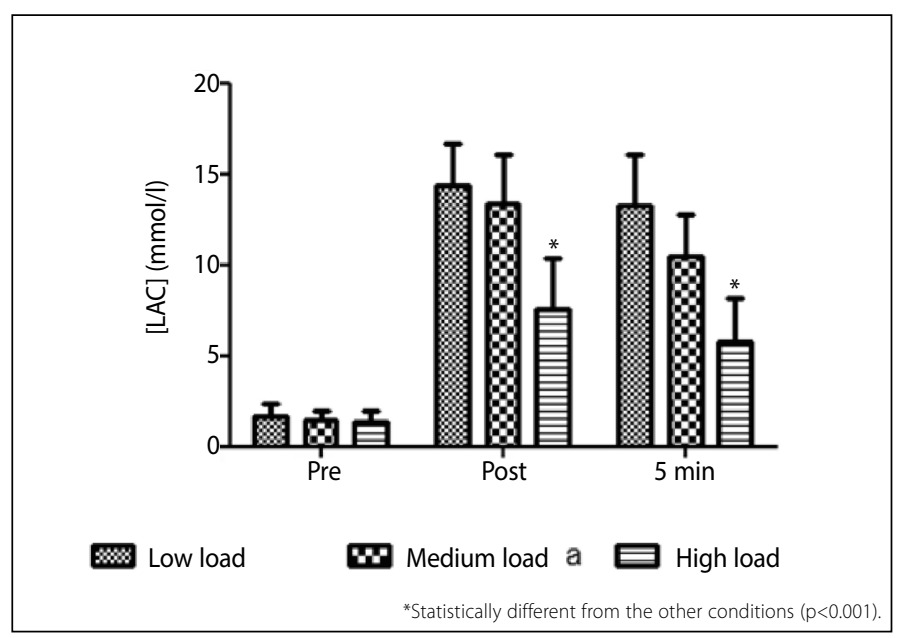

Figure 1. Blood lactate concentration for each training protocol.

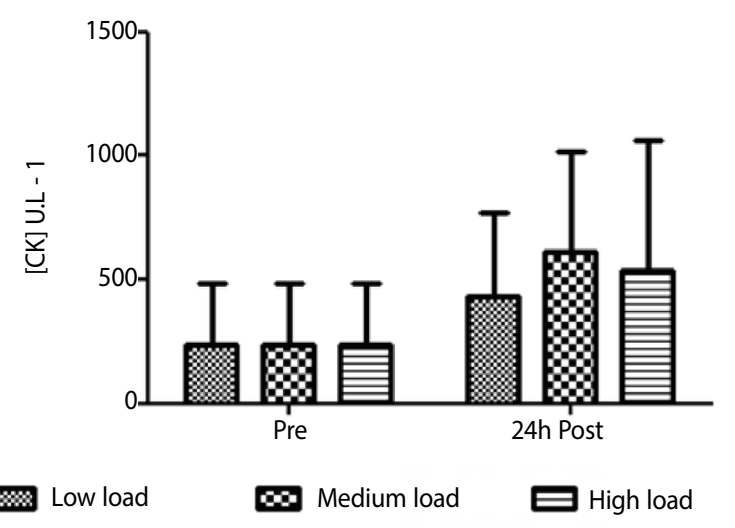

Figure 2. CK concentration for each session.

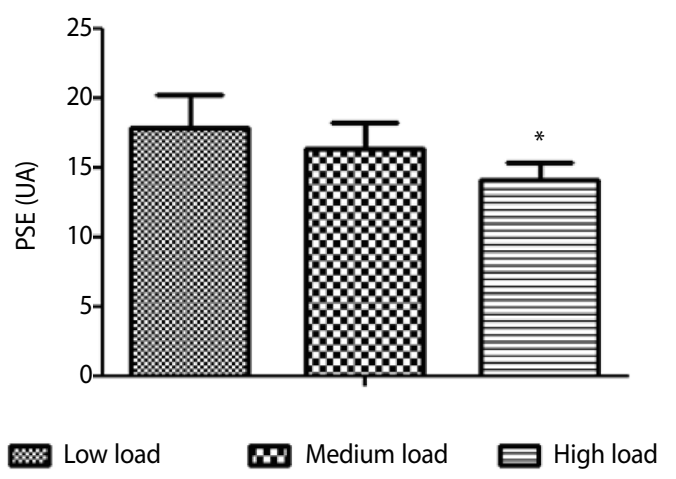

*Statistically different when compared to the training sessions with medium and low load ( $p<0.001)$.

Figure 3. Subjective perceived exertion in different training sessions. 
With regards to HRV in medium, low and high load training (Table 3), the results indicate differences between the pre and post-training time points for the time domain, frequency and nonlinear domain responses.

HR values are expressed in Table 4, and showed no significant differences when the three protocols were compared for resting heart rate $(\mathrm{RHR})(p=0.51)$, MeanHR $(p=0.26)$ and MaxHR $(p=0.87)$ either.

In the SBP analysis, no differences were observed between training sessions ( $F=0.98 ; p=0.38$ ), but instead between time points $(F=7.75$; $p<0.001)$, and there were no significant interactions ( $F=1.95 ; p=0.06)$. The Bonferroni post-hoc test indicated that mean SBP at the post-squat

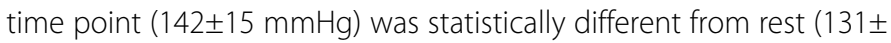
$11 \mathrm{mmHg} ; p=0.01)$, and from the post-bench press $(125 \pm 12 \mathrm{mmHg}$; $p<0.001)$, deadlift $(126 \pm 22 \mathrm{mmHg} ; p=0.001)$ and bent-over row exercise $(124 \pm 27 \mathrm{mmHg} ; p=0.003)$ time points. For DBP, no effect of training type $(F=1.62 ; p=0.21)$ and timing $(F=0.52 ; p=0.71)$ was observed. Mean resting values were $69 \pm 7 \mathrm{mmHg}$, post-squat $70 \pm 9 \mathrm{mmHg}$, post-bench press $70 \pm 10 \mathrm{mmHg}$, post-deadlift $67 \pm 13 \mathrm{mmHg}$, and end-of-session values were $69 \pm 17 \mathrm{mmHg}$.

\section{DISCUSSION}

The purpose of this study was to measure and compare the acute effect of different ST protocols on HR, HRV, [LAC], [CK] and SPE. Among the main findings, it is important to note that training with high loads generated lower values [LAC] when compared to the other training protocols. Regarding [CK], no differences were observed in the measurement $24 \mathrm{~h}$ after the training protocol, and for SPE higher values were recorded for the training sessions with medium and low load. For BP and HR and HRV no differences were observed between the training protocols.

Thus, it is understood that intervals of less than $3 \mathrm{~min}$ between sets can cause greater accumulation of [LAC] in physically active subjects in the bench press exercise with workload at $70 \%$ of maximal strength. ${ }^{25}$
Similarly, our study showed that in training with shorter intervals (45s and 90 s respectively), [LAC] values were higher when compared to training with an interval of 180 s.

As regards [CK], in a study that used 2 protocols for individuals undertaking ST, one group performed the protocol with a $1 \mathrm{~min}$ interval between sets and the other with a 3 min interval. For the 1 min interval group, the serum concentration of [CK] before the training session averaged less than $200 \mathrm{U} / \mathrm{L}$, increasing significantly $24 \mathrm{~h}$ after the training session (mean greater than $350 \mathrm{U} / \mathrm{L}$ ). Conversely, the group that trained with a $3 \mathrm{~min}$ interval showed no significant difference between times before and after the training session. In this particular study, no differences were found between protocols when comparing [CK] values $24 \mathrm{~h}$ after training, which may be due to the reduced monitoring time.

With regards to SPE, in terms of the variable interval between sets, a study that evaluated oxygen consumption during different interval periods (1, 2, 3 and $5 \mathrm{~min}$ ) between sets in the bench press exercise, in individuals accustomed to resistance training, showed that the shorter the interval (in the study in question this was $1 \mathrm{~min}$ ), the higher the oxygen consumption of the subjects, ${ }^{26}$ which is associated with a higher rate of fatigue, and is directly related to an increase in SPE. This is consistent with our research study, where the subjects reported higher SPE in resistance training (low load) and hypertrophy (medium load), even though these were performed with the lowest total weight.

Regarding the use of HRV in different strength training protocols, it would appear that performing submaximal workouts (four sets of eight repetitions

Table 4. Heart rate values for each training protocol (BPM) (mean $\pm \mathrm{sd})$.

\begin{tabular}{c|c|c|c}
\hline Type of load & Rest HR & Mean HR & Max HR \\
\hline Low & $62 \pm 10$ & $106 \pm 10$ & $173 \pm 16$ \\
\hline Medium & $61 \pm 12$ & $118 \pm 11$ & $178 \pm 8$ \\
\hline High & $62 \pm 12$ & $112 \pm 10$ & $174 \pm 9$ \\
\hline
\end{tabular}

${ }_{\text {Rest }} \mathrm{HR}=$ Resting heart rate; MaxHR= Maximum heart rate; MeanHR= Mean heart rate.

Table 3. Behavior of heart rate variability in three weight training protocols $(n=11)$.

\begin{tabular}{|c|c|c|c|c|c|c|c|c|c|c|c|c|}
\hline & & Low load & & & $\begin{array}{l}\text { Medium } \\
\text { load }\end{array}$ & & & High load & & & Time & \\
\hline & $\begin{array}{c}\text { Pre- } \\
\text { training }\end{array}$ & $\begin{array}{c}\text { Post- } \\
\text { training }\end{array}$ & $24 \mathrm{~h}$ after & $\begin{array}{c}\text { Pre- } \\
\text { training }\end{array}$ & Post-training & $24 \mathrm{~h}$ after & Pre-training & Post-training & $24 \mathrm{~h}$ after & $F$ & $\mathbf{P}$ & $\eta_{p}^{2}$ \\
\hline \multicolumn{13}{|l|}{ Time domain } \\
\hline MeanRR (ms) & $867.3 \pm 185.62$ & $547.6 \pm 63.52$ & $866.1 \pm 124.00$ & $875.4 \pm 170.78$ & $575.6 \pm 40.63^{*}$ & $883.1 \pm 183.84$ & $898.9 \pm 179.64$ & $623.5 \pm 75.52$ & $841.3 \pm 132.20$ & 86.11 & $<0.001^{*}$ & 0.74 \\
\hline MeanHR (ms) & $72.4 \pm 14.80$ & $111.3 \pm 13.02$ & $70.9 \pm 10.47$ & $71.6 \pm 14.77$ & $104.9 \pm 7.62^{*}$ & $71.5 \pm 15.92$ & $69.2 \pm 23.85$ & $98.7 \pm 12.85$ & $73.6 \pm 11.91$ & 144.84 & $<0.001^{*}$ & 0.83 \\
\hline SDNN (ms)\# & $61.4 \pm 28.91$ & $25.8 \pm 18.89$ & $52.9 \pm 22.82$ & $73.6 \pm 33.15$ & $19.7 \pm 6.28^{*}$ & $55.1 \pm 23.68$ & $57.6 \pm 19.80$ & $53.3 \pm 33.42$ & $60.0 \pm 30.86$ & 14.89 & $<0.001^{*}$ & 0.33 \\
\hline RMSSD (ms) & $27.8 \pm 11.82$ & $5.6 \pm 2.96$ & $22.9 \pm 5.55$ & $25.2 \pm 6.94$ & $5.8 \pm 2.58^{*}$ & $23.5 \pm 7.73$ & $27.0 \pm 10.44$ & $12.8 \pm 6.09$ & $23.1 \pm 5.80$ & 79.9 & $<0.001^{*}$ & 0.72 \\
\hline PNN50 (\%) & $5.5 \pm 4.63$ & $0.0 \pm 0.06$ & $4.5 \pm 3.83$ & $4.4 \pm 4.19$ & $0.0 \pm 0.00^{*}$ & $5.9 \pm 6.20$ & $5.0 \pm 3.78$ & $1.3 \pm 1.90$ & $4.2 \pm 3.39$ & 24.07 & $<0.001^{*}$ & 0.45 \\
\hline \multicolumn{13}{|l|}{ Frequency Dom. } \\
\hline $\operatorname{VLF}\left(\mathrm{ms}^{2}\right)$ & $\begin{array}{l}2228.0 \pm \\
3443.14\end{array}$ & $269.3 \pm 221.86$ & $\begin{array}{l}1706.9 \pm \\
1034.00\end{array}$ & $\begin{array}{c}8609.9 \pm \\
18455.73\end{array}$ & $157.6 \pm 112.43$ & $\begin{array}{c}1373.7 \pm \\
918.90\end{array}$ & $\begin{array}{l}1602.5 \pm \\
1415.88\end{array}$ & $\begin{array}{l}2918.3 \pm \\
4110.89\end{array}$ & $\begin{array}{l}2287.3 \pm \\
1842.67\end{array}$ & 2 & 0.17 & 0.06 \\
\hline VLF (\%) & $60.1 \pm 22.15$ & $80.6 \pm 9.58$ & $64.3 \pm 17.75$ & $74.0 \pm 17.46$ & $67.5 \pm 12.98$ & $62.9 \pm 13.44$ & $65.9 \pm 14.21$ & $73.0 \pm 17.65$ & $67.9 \pm 17.98$ & 3.4 & $0.04^{* * *}$ & 0.1 \\
\hline $\mathrm{LF}\left(\mathrm{ms}^{2}\right) \#$ & $458.3 \pm 309.93$ & $45.3 \pm 39.77$ & $548.9 \pm 355.40$ & $478.3 \pm 230.05$ & $67.0 \pm 56.00^{*}$ & $456.7 \pm 331.50$ & $399.4 \pm 166.34$ & $291.0 \pm 197.23$ & $455.9 \pm 256.56$ & 26.94 & $<0.001^{*}$ & 0.47 \\
\hline LF (\%) & $27.5 \pm 18.30$ & $16.9 \pm 8.19$ & $24.9 \pm 13.96$ & $19.6 \pm 16.13$ & $29.2 \pm 13.01$ & $27.8 \pm 14.13$ & $21.3 \pm 10.76$ & $21.1 \pm 16.09$ & $21.8 \pm 12.27$ & 0.37 & 0.7 & 0.01 \\
\hline LF (n.u) & $67.8 \pm 18.18$ & $86.0 \pm 9.76$ & $69.3 \pm 15.72$ & $72.79 \pm 16.27$ & $88.1 \pm 8.49^{*}$ & $71.3 \pm 16.67$ & $64.6 \pm 17.87$ & $79.2 \pm 19.03$ & $69.5 \pm 19.62$ & 14.13 & $<0.001^{*}$ & 0.32 \\
\hline $\mathrm{HF}\left(\mathrm{ms}^{2}\right)$ & $210.7 \pm 139.26$ & $5.9 \pm 5.13$ & $203.6 \pm 90.62$ & $182.2 \pm 116.11$ & $7.7 \pm 5.95^{*}$ & $181.4 \pm 111.95$ & $199.4 \pm 94.45$ & $83.4 \pm 93.77$ & $159.2 \pm 70.38$ & 41.04 & $<0.001^{*}$ & 0.58 \\
\hline HF (\%) & $12.4 \pm 10.77$ & $2.5 \pm 1.83$ & $10.7 \pm 7.61$ & $6.3 \pm 4.24$ & $3.2 \pm 1.36$ & $9.2 \pm 4.01$ & $12.8 \pm 10.78$ & $5.8 \pm 7.37$ & $33.5 \pm 81.22$ & 2.16 & 0.12 & 0.07 \\
\hline HF (n.u) & $32.1 \pm 18.15$ & $14.0 \pm 9.74$ & $30.6 \pm 15.61$ & $27.2 \pm 16.26$ & $11.7 \pm 8.06^{*}$ & $29.0 \pm 16.76$ & $35.3 \pm 17.78$ & $27.3 \pm 27.01$ & $30.5 \pm 19.59$ & 10.86 & $<0.001^{*}$ & 0.27 \\
\hline Total (ms) & $\begin{array}{l}2897.5 \pm \\
3584.46\end{array}$ & $320.5 \pm 254.07$ & $\begin{array}{l}2459.6 \pm \\
1189.94 \\
\end{array}$ & $\begin{array}{c}9270.2 \pm \\
18587.74 \\
\end{array}$ & $233.1 \pm 142.13$ & $\begin{array}{l}2012.1 \pm \\
1148.01 \\
\end{array}$ & $\begin{array}{l}2201.9 \pm \\
1493.81 \\
\end{array}$ & $\begin{array}{l}3293.2 \pm \\
4180.35\end{array}$ & $\begin{array}{l}2828.8 \pm \\
1972.97 \\
\end{array}$ & 2.47 & 0.12 & 0.08 \\
\hline LF/HF (\%) & $\begin{array}{l}3194.9 \pm \\
2417.99 \\
\end{array}$ & $\begin{array}{l}8560.5 \pm \\
4449.31 \\
\end{array}$ & $\begin{array}{l}3887.4 \pm \\
4688.59 \\
\end{array}$ & $\begin{array}{l}4483.5 \pm \\
3959.65 \\
\end{array}$ & $\begin{array}{l}11261.3 \pm \\
7461.33^{*}\end{array}$ & $\begin{array}{l}3999.9 \pm \\
3219.30 \\
\end{array}$ & $\begin{array}{l}3275.1 \pm \\
4299.65 \\
\end{array}$ & $\begin{array}{l}6532.8 \pm \\
4661.35 \\
\end{array}$ & $\begin{array}{l}2820.6 \pm \\
1629.32 \\
\end{array}$ & 19.23 & $<0.001^{*}$ & 0.39 \\
\hline \multicolumn{13}{|l|}{ Nonlinear dom. } \\
\hline SD1 (ms) & $19.7 \pm 8.38$ & $3.9 \pm 2.12$ & $16.2 \pm 3.94$ & $17.9 \pm 4.92$ & $4.1 \pm 1.85^{*}$ & $16.6 \pm 5.47$ & $19.2 \pm 7.40$ & $9.0 \pm 4.33$ & $16.5 \pm 4.11$ & 79.74 & $<0.001^{*}$ & 0.73 \\
\hline SD2 (ms)\# & $82.9 \pm 39.93$ & $36.0 \pm 26.71$ & $72.9 \pm 32.38$ & $101.9 \pm 46.95$ & $27.4 \pm 8.83^{*}$ & $75.6 \pm 34.00$ & $78.1 \pm 26.94$ & $74.5 \pm 47.26$ & $82.8 \pm 44.7$ & 13.19 & $<0.001^{*}$ & 0.31 \\
\hline
\end{tabular}


with a 3 min interval between sets with the load for 12 repetitions maximum) involves greater post-exertion sympathetic activity than training with maximum intensities (four sets with load for 12 repetitions maximum with a $3 \mathrm{~min}$ interval between sets, until voluntary failure). ${ }^{27}$ In addition, sessions at $80 \%$ of $1 \mathrm{RM}$, when compared with sessions at $60 \%$ and $70 \%$ of $1 \mathrm{RM}$, generated an increase in sympathetic tone and a decrease in parasympathetic tone. Moreover, the session at $80 \%$ of 1 RM can activate a higher number of motor units, with greater activation of the sympathetic nervous system to maintain a consistent number of repetitions in each set. ${ }^{28}$ However, in this study similar behavior was observed between the training protocols performed until failure, with a reduction in HRV at the post-exertion time point and a return to baseline levels measured $24 \mathrm{~h}$ after the intervention.

Regarding BP, when comparing different strength training volumes (three or six sets in five different exercises) in terms of hypotensive responses, the group that executed a higher workload was seen to benefit from the hypotensive effects of the exercise. ${ }^{29}$ Moreover, when maximal and submaximal strength training models are used, both protocols show statistically significant decreases in BP with a tendency for post-exertion blood pressure reductions, characterizing reductions in both SBP and DBP in both experimental groups, with more SBP reduction time points in the maximum intensity group. ${ }^{29}$ However, in this particular study no differences were observed between the protocols used, which featured variations in the load used, thereby implying the total volume of repetitions that the subject was able to perform until failure. This fact may be linked to the characteristics of the sample, given that a significant part of the population is not sensitive to the hypotensive effects of physical exercise.

\section{CONCLUSION}

It is suggested that training with high loads, few repetitions and longer intervals (maximum strength) generates lower blood lactate and SPE concentrations when compared to training using lower loads and shorter intervals (resistance training and hypertrophy). In addition, when the autonomic and cardiovascular variables are evaluated, it would appear that the act of manipulating the 1RM percentage and interval time is not capable of generating significant changes in HRV, BP and HR when repetitions are performed until failure.

All authors declare no potential conflict of interest related to this article

AUTHORS' CONTRIBUTIONS: Each author made significant individual contributions to this manuscript. AF: writing, revision, data analysis; RSV writing and revision; AXT: writing and data collection; LDC; writing, revision, data collection; FBDV: writing, revision, data analysis. All authors reviewed and approved the final version of the manuscript.

\section{REFERENCES}

1. Paz-Franco A, Rey E, Barcala-Furelos R. Effects of 3 Different resistance training frequencies on jump, sprint, and repeated sprint ability performance in professional futsal players. J Strength Cond Res. 2017;31(12):3343-50.

2. Seymore KD, Domire ZJ, DeVita P, Rider PM, Kulas AS. The effect of Nordic hamstring strength training on muscle architecture, stiffness, and strength. Eur J Appl Physiol. 2017;117(5):943-53.

3. Baechle TR, Earle RW. Essentials of strength training and conditioning/National Strength and Conditioning Association. 3rd ed. Champaign, IL: Human Kinetics; 2008.

4. Gunter K, Baxter-Jones AD, Mirwald RL, Almstedt H, Fuchs RK, Durski S, et al. Impact exercise increases BMC during growth: an 8-year longitudinal study. J Bone Miner Res. 2008;23(7):986-993.

5. Fiatarone MA, Marks EC, Ryan ND, Meredith CN, Lipsitz TZ, Evans WJ. High-intensity strength training in nonagenarians. Effects on skeletal muscle. JAMA 1990;263(2):3029-34.

6. Gentil P. Bases científicas do treinamento de hipertrofia. 5. ed. Rio de Janeiro: Sprint, 2014.

7. Campos GE, Luecke TJ, Wendeln HK, Toma K, Hagerman FC, Murray TF, et al. Muscular adaptations in response to three different resistance-training regimens: specificity of repetition maximum training zones. Eur J Apll Physiol. 2002;88(1-2): 50-60.

8. Balnave CD, Thompson MW. Effect of training on eccentric exercise-induced muscle damage. J App Physiol (1985). 1993;75(4):1545-51.

9. Wilmore JH, Costill DL. Fisiologia do Esporte e do Exercício. São Paulo: Manole, 2001.

10. Suzuki FG, Okuno NM, Lima-Silva, AE, Perandini LA, Kokubun E, Nakamura FY. Esforço percebido durante o treinamento intervalado na natação em intensidades abaixo e acima da velocidade crítica. Rev Port Cien Desp. 2007;7 (3):299-307

11. Vanni O, Tibana RA, Aguiar F, Nascimento DC, Santana FS, Balsamo S. Efeito de diferentes ordens dos exercícios de força no número de repetições, volume total de treino, percepção subjetiva de esforço e resposta lactacidêmica em homens destreinados. Braz J Biomot. 2011;5(4):221-9.

12. Nakamura FY, Moreira A, Aoki MS. Monitoramento da carga de treinamento: a percepção subjetiva do esforço da sessão é um método confiável? Rev Educ. Física/UEM. 2010;21(1):1-11.

13. Scott CB. Contribution of blood lactate to the energy expenditure of weight training. J Strength Cond Res. 2006;20(2):404-11.

14. Morandi RF, Coelho DB, de Melo MA, Silami-Garcia E. Cinética da creatina quinase em jogadores de futebol profissional em uma temporada competitiva. Rev Bras Cineantropom Desempenho Hum. 2011;13(3):189-94.

15. Vanderlei LC, Pastre CM, Hoshi RA, Carvalho TD, Godoy MF. Noções básicas de variabilidade da frequência cardíaca e sua aplicabilidade clínica. Rev Bras Cir Cardiovasc. 2009;24(2):205-17.
16. Simões RP, Mendes RG, Castello V, Machado HG, Almeida LB, Baldissera V, et al. Heart-rate variability and blood-lactate threshold interaction during progressive resistance exercise in healthy older men. $J$ Strength Cond Res. 2010;24(5):1313-20.

17. Rezk CC, Marrache RC, Tinucci T, Mion D Jr, Forjaz CL. Post-resistance exercise hypotension, hemodynamics, and heart rate variability: influence of exercise intensity. Eur J Appl Physiol. 2006;98(1):105-12

18. Figueiredo T, Willardson JM, Miranda H, Bentes CM, Machado Reis V, Freitas de Salles $B$, et al. Influence of rest interval length between sets on blood pressure and heart rate variability after a strength training session performed by prehypertensive men. J Strength Cond Res. 2016;30(7):1813-24.

19. Machado M, Koch AJ, Willardson JM, Pereira LS, Cardoso MI, Motta MK, et al. Effect of varying rest intervals between sets of assistance exercises on creatine kinase and lactate dehydrogenase responses. J Strength Cond Res. 2011; 25(5):1339-45.

20. American College of Sports Medicine. American College of Sports Medicine position stand. Progression models in resistance training for healthy adults. Med Sci Sports and Exerc. 2009;41(3):687-708.

21. Javorek J, Tersigni A. Health care of the future. Mich Health Hosp 1998; 34(2):28-9.

22. Mello TL, Rosa SM, Vaz MS, Del Vecchio FB. Treinamento de força em sessão com exercícios poliarticulares gera estresse cardiovascular inferior a sessão de treino com exercícios monoarticulares. Rev Bras Cienc Esporte. 2017;39(2):132-40

23. Borg GA, Noble BJ. Perceived exertion. In: Exercise and Sports Science Reviews. Wilmore JH (ed), New York: Academic Press, 1974;131-53.

24. Barth J, DelVecchio FB. Efeitos da frequência ventilatória sobre os índices da variabilidade da frequência cardíaca. Rev Iberoam Arritmol. 2014;5(1):185-93.

25. Abdessemed D, Duché P, Hautier C, Poumarat G, Bedu M. Effect of recovery duration on muscular power and blood lactate during the bench press exercise. Int I Sports Med. 1999;20(6):368-73.

26. Ratamess NA, Falvo MJ, Mangine GT, Hoffman JR, Faigenbaum AD, Kang J. The effect of rest interval length on metabolic responses to the bench press exercise. Eur J Appl Physiol. 2007;100(1):1-17.

27. Corrêa Neto VG, Bentes CM, Maranhão Neto GA, Miranda H. Hipotensão e variabilidade da frequência cardíaca pós-exercício de força executado de forma máxima e submáxima. Motri. 2017;13(1):19-29.

28. Secher, NH. Heart rate at the onset of static exercise in man with partial neuromuscular blockade. $J$ Physiol. 1985. 368:481-90.

29. Polito MD, Simão R, Senna GW, Farinatti PT. Efeito hipotensivo do exercício de força realizado em intensidades diferentes e mesmo volume de trabalho. Rev Bras Med Esporte. 2003;9(2):69-73. 